\title{
Is the graduate attributes approach sufficient to develop work ready graduates?
}

\author{
Srivalli Nagarajan ${ }^{1}$, Jenny Edwards ${ }^{2}$ \\ srivalli.nagarajan@sydney.edu.au; jenny.edwards@uts.edu.au \\ ${ }^{1}$ The University of Sydney, ${ }^{2}$ University of Technology, Sydney
}

\begin{abstract}
Many universities have graduate attributes, sometimes referred to as generic skills, soft skills or work ready skills. This paper reports a study of the professional work experiences of recent Australian Information Technology (IT) graduates who identified that communication, time management, teamwork, working with people, working across cultures, project management and business skills were some of the major professional skills required for their work. A discussion of the study and its findings raises questions about the adequacy of the graduate attributes approach in the development of professional skills such as the ability of to work across cultures and on multiple projects which are major requirements of graduates in many IT (and other) workplaces. The study reveals the IT graduates' perspectives on the challenges they faced at work, the typical professional skills requirements of their practice and how they acquired or developed them, the elements of their university study which had relevance to the required workplace professional skills and how well their studies prepared them to meet the professional needs of their practice.
\end{abstract}

Keywords: IT or ICT education, graduate attributes, graduate employability, work ready graduates, work ready skills, graduate work experiences.

\section{Introduction}

Graduate attributes are defined by the Australian Technology Network (Bowden, Hart, King, Trigwell \& Watts, 2000) as:

the qualities, skills and understandings a university community agrees its students would desirably develop during their time at the institution and consequently shape the contribution they are able to make to their profession and as a citizen.

Sometimes referred to as generic skills, transferable skills, core skills, soft skills, graduate capabilities, work-ready skills and key skills, graduate attributes are no longer seen as being independent of discipline knowledge because they interact with discipline knowledge. They are a specialised and differentiated form of understanding generic abilities, which are developed to meet the needs of a specific discipline or field of knowledge (Barrie, 2004). According to James et al. (2004) graduate attribute development takes place mostly within disciplines. Kamvounias and Thompson (2008) agree, reporting that the term 'generic' is sometimes misinterpreted as independent of the field of study, implying development in a separate unit of study. They refer to this as a 'bolted on' approach.

All Australian universities identify the graduate attributes to be attained by their students. Often, particular courses have their own attributes in addition, or as an alternative to the university's generic graduate attributes (experiences of one of the authors as a government 
and discipline accreditor). For example, a generic graduate attribute for communication skills may be expressed in an engineering course, as a requirement for graduates to exercise effective communication to arrive at design and problem solutions while working as a team. The desire to provide a coherent approach to the embedding of graduate attributes into courses of study led to some Australian universities introducing a graduate attributes framework as a policy led initiative for the design and accreditation of courses (Boud \& Solomon, 2006).

At times there are high or perhaps unrealistic expectations of universities to guarantee that their students possess the desirable skills identified in the graduate attributes espoused by institutions (Hager \& Holland, 2006; Lowden, Hall, Elliot \& Lewin, 2011; Seitel, 2011). A more reasonable guarantee might be that graduates will be provided with as many opportunities as possible to acquire and develop these generic skills during their study program. However, the fact that university courses differ in length, coverage of content, focus within subjects, etc., complicates the task of developing an overall approach to the development of a set of generic attributes for graduates, if this is indeed desirable. Similarly, academics, usually appointed for their expertise in their discipline and research achievements, will have a varying commitment to and success in the application of the concept of generic attributes to their discipline.

In 2009, partially as a response to the Bradley review of higher education (Bradley, Noonan, Nugent \& Scales, 2008), the Australian Government commissioned the Australian Learning and Teaching Council (ALTC) to work with discipline communities on the Learning and Teaching Academic Standards Project. The aim of the resulting ALTC's Discipline Scholars 2010 program was to enhance student learning and learning outcomes by working closely with the nationwide discipline specific bodies (ALTC, 2010a). The Discipline Scholars developed five threshold learning outcome areas for Engineering and ICT graduates after consultation with the industry, academics, students, Engineers Australia (EA) and the Australian Computer Society (ACS) (ALTC, 2010b). Also taken into account was the current accreditation process of EA and the ACS (ALTC, 2010c). The five threshold learning outcome areas are: Needs, context and systems; Problem solving and design; Abstraction and modelling; Coordination and communication, and Self-management (Wright, Hadgraft, \& Cameron, 2010). These are similar to many of the major professional skill categories identified in this study (see Table 2).

Accreditation bodies have made a significant contribution to the discourse on graduate attributes. For example, the ACS is responsible for Australian Information Technology (IT) course accreditation in Australia and, although optional, most institutions seek it. Accreditation requires a certain depth and breadth of knowledge in key areas. More importantly, it mandates the learning of generic skills such as project management, ethics and written and oral communication (ACS, 2013). Universities are required to submit a detailed mapping of graduate attributes to assessment and learning outcomes. While the spotlight remains on the development of graduate attributes, whether or not universities are successful in achieving this remains uncertain. This paper seeks to address the question of how IT graduates perceive the effectiveness of their undergraduate IT study program in developing the graduate attributes required for their professional workplace.

The next section reviews the relevant literature and is followed by an outline of the methodology and the findings of the study. Subsequently there is a discussion of the role of graduate attributes in Australian universities, the relationship between graduate attributes and employability skills, why graduate attributes should not be an add-on to existing courses and the need to have graduate attributes embedded in discipline-specific subjects. Finally, there is a consideration of an area of professional skill that does not appear to be addressed adequately by existing graduate attributes for IT graduates. 


\section{Development of graduate attributes during university studies}

Although skills and attributes are often used interchangeably they have different meanings. Skills are typically practical such as communication, time management and teamwork. Graduate attributes are usually broader than skills and include qualities such as loyalty, commitment, honesty and integrity. Such qualities, which have been found to be highly desirable by employers (Crebert, Bates, Bell, Patrick \& Cragnolini, 2004a) are usually considered to be attributes rather than skills.

Similarly, there is a great deal of variation in the ways in which academics not only interpret or define graduate attributes, but also in how committed they are to particular approaches to developing graduate attributes or indeed to whether they should be taught at all (Barrie, 2004). Boud and Solomon (2006) suggest that graduate attributes will work only if those to whom they are exposed are willing players in the process and are in a position to appreciate the qualities developed. Despite the disparate views, most Australian universities mandate that academics include graduate attributes in their curriculum documentation (see, for example, Deakin University, 2013).

Kamvounias and Thompson (2008) state that graduate attributes can be conceptualised at different institutional levels such as university, faculty, school, department, program of study and particular subjects. Such a conceptualisation does present challenges for curriculum development. One approach to managing the varying levels is the use of overarching graduate attributes that are then broken down to specifics that can be implemented at lower levels. Subsequently, these graduate attributes are translated by the faculty into a set of more specific learning goals relevant to the degrees. The successful development of graduate attributes may then be facilitated by aligning learning design, learning outcomes, teaching and learning activities, and assessment criteria and tasks with the graduate attributes.

The further challenge for academics then becomes the tracking and assessment of the development of graduate attributes. In some cases this might result in a tick-box mapping exercise where, in reality, the learning goals are matched with graduate attributes. In other instances graduate attributes are mapped to learning outcomes and assessment tasks, but not necessarily mapped to the assessment criteria (Kamvounias \& Thompson, 2008). However, mapping graduate attributes does not ensure that they are taught explicitly, If not made explicit, the students may focus on obtaining the required marks or grades and remain unaware of, or disinterested in, the graduate attributes which may have been implicit in assessment tasks and criteria.

Worldwide, employers demand that the graduates they hire should 'fit' and add value to the business in the short-term and long-term (Nankervis, Compton \& Baird, 2005). Many employers assume that graduates have the required academic skills (Yorke, 2006). Yorke discusses the preparation of graduates for work as a two-layered approach. Job-readiness is the first layer of a student's preparation for the workforce and it is linked to professional knowledge. Employability is the second layer of student preparation and involves the ability and willingness of graduates to think beyond knowledge. The employer perspectives are reflected by this layer. When difficulties or challenges arise at work, graduates need to be able to combine the most appropriate knowledge for the situation, i.e. both job-specific skills and generic skills, to develop an ability to read the situation and determine a suitable strategy. Scott and Yates (2002) describe this as professional capability. They discuss whether individual graduates can be 'emotionally intelligent' (graduates with higher order personal and interpersonal skills who can problem solve, think creatively, communicate, negotiate and find solutions rather than know them) and whether or not, universities have contributed to the initiation or fostering of such skills. They conclude that while technical enterprise is a necessary capability, it is certainly not sufficient to produce a successful graduate. 
James, Lefoe \& Hadi (2004) argue that the development of graduate attributes is a shared responsibility of teachers and students. Furthermore, graduate attributes should not just be viewed as a compliance issue, but instead used as a medium for good teaching practice and the development of a community of practice. They discuss knowledge, purpose and graduate attributes where knowledge includes cognitive understanding (disciplinary) and affective knowledge (values and attitudes, such as commitment capability etc.). James et al. (2004) also propose some ways to illuminate graduate attributes in teaching such as sharing teaching strategies across different faculties through online web-based platforms. An extension of this is the notion of developing communities of practice within a university to collaborate on graduate attributes and teaching strategies (Wenger, McDermott \& Snyder, 2002). Such communities of practice would encourage sharing by academics of strategies used in teaching to develop graduate attributes resulting in the dissemination of good practice to achieve graduate attributes.

Some of the practical challenges to overcome are the complexity of course structures and the flow-on effect that curriculum changes can have on other university systems. For example, Barrie (2004) states that universities often find it difficult to embed and assess graduate attributes and that these are not really tested until students enter the workforce. To date, graduate attributes do not appear to be a well-advertised concept among graduates. Universities and departments need to do more to make their graduates aware of the attributes they should acquire as a result of undertaking a particular degree. Explicit connections between learning, assessments and graduates attributes are required for graduates to appreciate and be aware of their development of graduate attributes (Thompson, Treleaven, Kamvounias, Beem \& Hill, 2008). Critical to the achievement of this is stakeholder feedback. Feedback from employers may assist in the development of workreadiness through applications of knowledge and skills to authentic work situations. Similarly, student surveys will provide valuable feedback on learning experiences, while student engagement may be reflected in information relating to retention rates.

In addition to responding to stakeholders, universities are under pressure by moves in education and labour market policy to produce employable graduates (Bridgstock, 2009) and this has increased the focus on graduate attributes and their relationship to employability skills. That is, graduates increasingly need the ability to navigate the world of work and selfmanage the career building process (Bridgestock, 2009). Similarly, Harvey (2001) defines employability skills as those that pertain to an individual's capacity to obtain and maintain work and contribute to economic productivity.

The employability skills framework (DEST, 2002) developed by the Australian Chamber of Commerce and Industry $(\mathrm{ACCl})$ and the Business Council of Australia (BCA) use the following definition of employability skills:

Skills required not only to gain employment but also to progress within an enterprise so as to achieve one's potential and contribute successfully to enterprise strategic directions

Eight employability skills and broad personal attributes across all industry sectors are identified in the Framework. They are:

1. Communication;

2. Teamwork;

3. Problem-solving;

4. Self-management;

5. Planning and organizing;

6. Technology;

7. Lifelong learning; and

8. Initiative and enterprise. 
Employability skills and work readiness have also been used interchangeably. In relation to IT, Litchfield and Nettleton (2008) gathered definitions for work readiness as defined by professional societies such as the ACS and the Department of Education, Science and Technology (DEST) now known as Department of Industry. A common list of key graduate attribute descriptors was found. They were global perspectives, communications capacity, ability to work well in teams, ability to apply knowledge, creative problem solving and critical thinking skills, professionalism and ethics, and the ability to apply knowledge. Despite these efforts to define employability skills, there is no systematic framework in higher education to embed these skills within the curriculum. The sector is reliant on graduate attributes as a vehicle to deliver these employability skills during the course of study (Oliver, Jones, Ferns, \& Tucker, 2007a).

While there is general agreement that it is desirable to ensure alignment in curricula by embedding and assessing learning outcomes derived from institutional graduate attributes (Biggs, 2003), in practice this is not always achieved. Indeed, at some universities graduate attributes remain at the level of intended or desired outcomes for students. Barrie and Prosser (2003) observe that graduate attributes have their roots in the contested territory of questions as to the nature of knowledge and nature of a university. Etzkowitz and Leydesdorff (2000), view graduate attributes not as a representation of displacement of one approach to knowledge production by another, but rather a change in priority for the types of knowledge sought. The debate about whether universities see themselves as major players preparing graduates for work is not over.

This study contributes to this debate through an investigation of graduates' perceptions of how relevant their university studies were to the professional workplace. The next section describes the study and presents some findings that demonstrate that IT graduates were not sufficiently prepared in some professional areas (for example, working across cultures). We ask: What purpose do graduate attributes serve in the light of such findings? Does the graduate attribute approach work? Is the graduate attributes approach sufficient to develop work ready graduates, especially in IT?

\section{Methodology}

To understand the professional skill requirements of IT workplaces and to understand the preparation of university IT graduates for work, the professional work experiences of twenty four local and international graduates with IT Bachelor's degrees from New South Wales, Australia were analysed. They were recent graduates, i.e. from the last three years and had studied as full-time students. They had all been employed at the time of the study in a paid IT professional position for 0.5-3 years. The graduates could have completed work experience as a formal part of their university course, but graduates who did not study as full-time students were excluded as they may have been working during university study and could have developed some workplace skills from these jobs. Participants came from a broad spectrum of cultural and ethnic backgrounds, worked for small, medium and large sized companies that were either multinational or local and were employed across a variety of IT roles. Table 1 shows the profile of the participants.

Table 1: Profile of study participants

\begin{tabular}{cclll}
\hline Participant & $\begin{array}{c}\text { Location/ } \\
\text { data } \\
\text { collection }\end{array}$ & $\begin{array}{c}\text { Participant } \\
\text { background }\end{array}$ & $\begin{array}{c}\text { IT work } \\
\text { experience }\end{array}$ & \multicolumn{1}{c}{ Responsibilities/work areas } \\
\hline 1 & $\begin{array}{c}\text { Sydney } \\
\text { NSW }\end{array}$ & $\begin{array}{l}\text { Bachelor of } \\
\text { Science degree }\end{array}$ & $\begin{array}{l}<\text { three } \\
\text { years }\end{array}$ & $\begin{array}{l}\text { Web design, marketing and coordination of web } \\
\text { based campaigns, sales of IT services and } \\
\text { in IT from a } \\
\text { (Interviewed) }\end{array}$ \\
& $\begin{array}{l}\text { Sydney } \\
\text { University }\end{array}$ & & \\
& & &
\end{tabular}


9

10

(n)

(

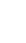

\section{Sydney \\ NSW \\ (Interviewed)}

\section{Sydney}

NSW

(Interviewed) $\begin{array}{ll}\text { Software } \\ \text { Engineering } \\ \text { from a Sydney }\end{array}$

from a Sydney

University

Sydney

NSW

(Interviewed)

Sydney

NSW

(Interviewed)

Bachelor degree in IT

from a Sydney

University

Sydney

NSW

(Interviewed)

Bachelor degree in IT

from a Sydney

University

\section{Sydney}

NSW

Bachelor degree in IT

from a Sydney

University

(Interviewed)

Bachelor

degree in IT

from a Sydney

ACT

University

(Interviewed)

Bachelor

degree in IT

from a regional

NSW

University

\section{Sydney}

NSW

Bachelor

(Interviewed)

degree in IT

Sydney

NSW

(Interviewed)

from a Sydney

University

NSW
(Interviewed)
Sydney
NSW
(Interviewed)
NSW
(Surveyed
online)

Bachelor

degree in IT

from a Sydney

University

NSW
(Surveyed
online)

Bachelor

degree in IT

from a Sydney

University

VIC
(Surveyed
online)

Bachelor

degree in IT

related

discipline NSW

$<$ one year

$<$ three

years

$<$ three

years

$<$ three

years

$>$ three

years

$<$ three

years

Bachelor

degree in IT

related

discipline NSW

Bachelor

degree in IT

related

discipline from

VIC

NSW
(Surveyed
online)

Bachelor

degree in IT

related

discipline NSW

$\begin{array}{ll}\text { NSW } & \begin{array}{l}\text { Bachelor } \\ \text { degree in IT } \\ \text { related }\end{array}\end{array}$

$<$ three

years

$<$ three

years

1 year

3 years

1 year

2 years

2 years
Professional services to telecommunication companies, technical and strategic solutions, advisory role, training

Business analysis, client management, training in a consulting firm

Software development, systems integration, network management, business reporting, support marketing of IT services and solutions

In a two year graduate program. Currently doing IT auditing of internal company systems, previously in business analysis, architecture, design, programming and testing roles

Network administration, hardware replacement, team member in a networking company

Applications development, programming roles during the first three years of IT work

Systems development, database administration, systems testing

IT support, troubleshooting, network management role in an academic institution

Team leader for software development team, project management, testing, support, defect management

Business rules, system navigation and flow, legal $\&$ regulatory requirements, customer experience requirements, and controls

Customer support role

Security compliance functions

Programming and database administration

Network administration and management

Business analysis and project management 


\begin{tabular}{|c|c|c|c|c|}
\hline & online) & discipline NSW & & \\
\hline 17 & $\begin{array}{l}\text { NSW } \\
\text { (Surveyed } \\
\text { online) }\end{array}$ & $\begin{array}{l}\text { Bachelor } \\
\text { degree in IT } \\
\text { related } \\
\text { discipline NSW }\end{array}$ & 1 year & $\begin{array}{l}\text { Database administration, report generation IT } \\
\text { audit }\end{array}$ \\
\hline 18 & $\begin{array}{l}\text { NSW } \\
\text { (Surveyed } \\
\text { online) }\end{array}$ & $\begin{array}{l}\text { Bachelor } \\
\text { degree in IT } \\
\text { related } \\
\text { discipline NSW }\end{array}$ & 1 year & $\begin{array}{l}\text { IT / Network Security - Ensuring phishing sites } \\
\text { targeting are disabled, reverse engineering } \\
\text { malware, predicting future malware threats and } \\
\text { improving online collaborative environment for } \\
\text { large decentralised team }\end{array}$ \\
\hline 19 & $\begin{array}{l}\text { NSW } \\
\text { (Surveyed } \\
\text { online) }\end{array}$ & $\begin{array}{l}\text { Bachelor } \\
\text { degree in IT } \\
\text { NSW }\end{array}$ & 2 years & $\begin{array}{l}\text { Project manager, business analyst and developer } \\
\text { for } 4 \text { small automation projects }\end{array}$ \\
\hline 20 & $\begin{array}{l}\text { NSW } \\
\text { (Surveyed } \\
\text { online) }\end{array}$ & $\begin{array}{l}\text { Bachelor } \\
\text { degree in IT } \\
\text { related } \\
\text { discipline NSW }\end{array}$ & 2 years & $\begin{array}{l}\text { Database administrator, system administrator and } \\
\text { general support. }\end{array}$ \\
\hline 21 & $\begin{array}{l}\text { NSW } \\
\text { (Surveyed } \\
\text { online) }\end{array}$ & $\begin{array}{l}\text { Bachelor } \\
\text { degree in IT or } \\
\text { related } \\
\text { discipline NSW }\end{array}$ & 2 years & $\begin{array}{l}\text { Business analysis - risk mitigation, requirements } \\
\text { determination, business process redesign, } \\
\text { facilitate interviews/meetings. }\end{array}$ \\
\hline 22 & $\begin{array}{l}\text { NSW } \\
\text { (Surveyed } \\
\text { online) }\end{array}$ & $\begin{array}{l}\text { Bachelor } \\
\text { degree in IT } \\
\text { related } \\
\text { discipline }\end{array}$ & 2 years & $\begin{array}{l}\text { IT project manager, develop computer solutions } \\
\text { for business processes, assist in the development } \\
\text { of strategies that demonstrate best practice, } \\
\text { change management and communication, liaise } \\
\text { with users to assist with business and system } \\
\text { related issues, project manage the } \\
\text { implementation of applications, overall IT project } \\
\text { testing, implementation and maintenance }\end{array}$ \\
\hline 23 & $\begin{array}{l}\text { NSW } \\
\text { (Surveyed } \\
\text { online) }\end{array}$ & $\begin{array}{l}\text { Bachelor } \\
\text { degree in IT } \\
\text { related } \\
\text { discipline NSW }\end{array}$ & 1 year & Website design and development \\
\hline 24 & $\begin{array}{l}\text { NSW } \\
\text { (Surveyed } \\
\text { online) }\end{array}$ & $\begin{array}{l}\text { Bachelor } \\
\text { degree in IT } \\
\text { related } \\
\text { discipline NSW }\end{array}$ & 2 years & Quality assurance, software testing, team leader \\
\hline
\end{tabular}

The focus of the study was on the professional skills and work experiences of recent Australian IT graduates, an area which requires investigation and greater clarity of understanding. It explored what graduates actually do in their professional practice and the challenges they face in workplaces. It endeavoured to understand the role and responsibilities of universities, employers and professional associations in the professional skills development of IT graduates. These issues required an approach that generated a rich conceptual description of the professional skills and work experiences of IT graduates. Thus, an approach using ideas from grounded theory such as constant comparison, theoretical sampling, open coding, axial coding, selective coding and theoretical saturation was employed. Interviews and qualitative online surveys were the research methods used.

\section{Data Collection and Analysis}

Data collection and data analysis occurred concurrently. As the interviews were completed, they were transcribed. Each transcript was then read carefully and the phrases were chunked. Subsequently, phrases of each interview were taken and each piece of "chunked data' was coded with a code name (open coding). The data from one interview were constantly compared with the other interviews and the same codes were used in all the transcriptions when there were similarities identified. Once concepts (codes) were identified they were grouped to form sub-categories. In axial coding, the codes were reviewed again (for relationship between sub-categories) and grouped into minor categories. As interview and survey data were subjected to further constant comparison it was necessary to create 
new categories and merge some existing categories resulting in major categories. Further grouping of major categories resulted in the emergence of five themes.

$\begin{array}{ll}\text { Theme 1 } & \begin{array}{l}\text { Professional skills IT graduates believe are required for their work } \\ \text { Theme 2 }\end{array} \\ \text { Theme 3 } & \begin{array}{l}\text { Sources of professional skills for IT graduates } \\ \text { Most useful aspects of university studies that IT graduates believe } \\ \text { contributed towards their professional skills development }\end{array} \\ \text { Theme 4 } & \begin{array}{l}\text { Challenges faced by IT graduates at workplaces } \\ \text { Graduate perceptions of differences between university and the } \\ \text { Theme 5 }\end{array} \\ & \text { workplace in the application of professional skills. }\end{array}$

Only themes 1 and 2 will be discussed in this paper.

\section{Study findings}

Table 2 provides a detailed view of the different professional skills IT graduates believe are required for their work. There are eight major categories: communication, time management, teamwork, working with people, working across cultures, project management, business and personal skills.

There are multiple and complex relationships across the categories of the eight professional skills. Communication is the dominant skill category that is related to all other categories. The study showed that some skills are applied differently in different work contexts across different organisations and the professional skill requirements also vary from one employer to another, although the nature of work may be the same. These findings have implications for university courses and their commitment to preparing work ready graduates.

\section{Table 2: Major Categories for Professional Skills IT Graduates Believe are Required for their Work}

$\begin{array}{ll}\text { Major } & \text { Details of sub categories of skills } \\ \text { Category }\end{array}$

Communication Use of language in communication with clients/peers/superiors

Skills Communication style (formal versus informal)

Communication mode (verbal, written, e-mail, online, face-to-face meetings)

Documenting communication

Structure of messages, choice of language in business and technical communication

Ability to communicate bad news-tactical communication

Communication with senior colleagues and people from different cultures

Communication in an international work environment with people from different cultures

Meeting facilitation, feedback communication

Communication to solve problems, communication to sell ideas

Timeliness of communication

Time Schedule management (projects, resources) with different project duration

management Time management in an international work environment with people from different time zones

skills

Use of technology, tools and techniques to manage time

Multitasking ability, timely delegation/escalation of issues

Handling different workloads (under, normal, over, crisis)

Timeliness of work delivery, handling pressure and time management for self and for the team

Teamwork skills

Team dynamics, Nature of teams (formal, informal) and team player

Team size and composition, international team, handling feedback to and from team

Team monitoring and motivation

Use of technology, tools and techniques for team interaction 
Handling team conflicts and negotiation

Pre meeting planning and management, conducting meetings, post meeting tasks

$\begin{array}{ll}\text { Working with } & \text { Managing expectations of manager, forecast stakeholder reaction } \\ \text { people } & \text { Managing client expectations, managing team expectations, work-life balance } \\ \text { Building trust, professional relationship with clients } \\ \text { Being aware of hierarchical work relationships } \\ \text { Use of appropriate conflict management strategies to resolve problems at work } \\ \text { Ability to work with competent and incompetent peers } \\ \text { Assisting managers with recruitment of staff } \\ \text { Ability to care for customers and build good relationships } \\ \text { Understanding customers from different cultural backgrounds and customer relationship } \\ \text { management, use of appropriate customer service strategies }\end{array}$

Working across cultures

Project management

Business Skills

Personal Attributes
Ability to work with people from different work culture (business, IT, international and interstate sites)

Ability to work with international people from different work culture

Cultural communication style (choice of correct writing style)

Being aware of language issues and local customs when working on international sites Language barriers

Change management, quality assurance, research and information management, infrastructure management, scope management, resources management, cost and time management Work delegation, job competency (analysis, research, logical, economical) Managing risk issues in work processes, managing product related risks Compliance and work accountability, following company procedures while handling problems Use or development of appropriate problem solving strategies
Understanding management style and work procedures, product knowledge
Business knowledge, business analysis, business representation
Ability to promote products, ideas and services
Understanding the importance of marketing and stakeholder relationships
Understanding team dynamics, performance appraisal skills
Information gathering skills, Information processing skills

Adapting to dynamic work requirements, ability to assess one's strengths and weakness Emotional intelligence, ability to confidently conduct oneself, passion/enthusiasm for the job Work ethic, experiential learning, ability to develop new skills

The graduates in the study believe that they developed the professional skills they needed for work from many sources, just one of which was university study, as shown in Figure 1. Furthermore, it was revealed that some aspects of university IT studies are more useful and relevant for IT workplaces than others. Work placement and project work are the aspects of university study that all IT graduates found most useful in the workforce. The majority of the challenges that the graduates face are in the category Working with people. Issues such as age differences, gender domination, managing expectations, lack of recognition, lack of support, insufficient induction, mentoring, professional relationships and professional development are particular challenges in this category and are distributed across the professional skill areas identified in this study. Graduates use a combination of strategies to cope with these challenges. They believe that some professional skills such as standards of work submission are applied differently in work contexts than those developed at university.

Time management strategies were learned from both university studies as well as on the job, but other skills were developed outside university. Some skills, for example, working with international clients in different time zones and from different cultures could be 
sufficiently developed only when graduates have commenced employment. Such findings have implications for universities' claims that they are preparing work ready graduates and raise questions about the achievement of graduate attributes stated in the university curriculum.

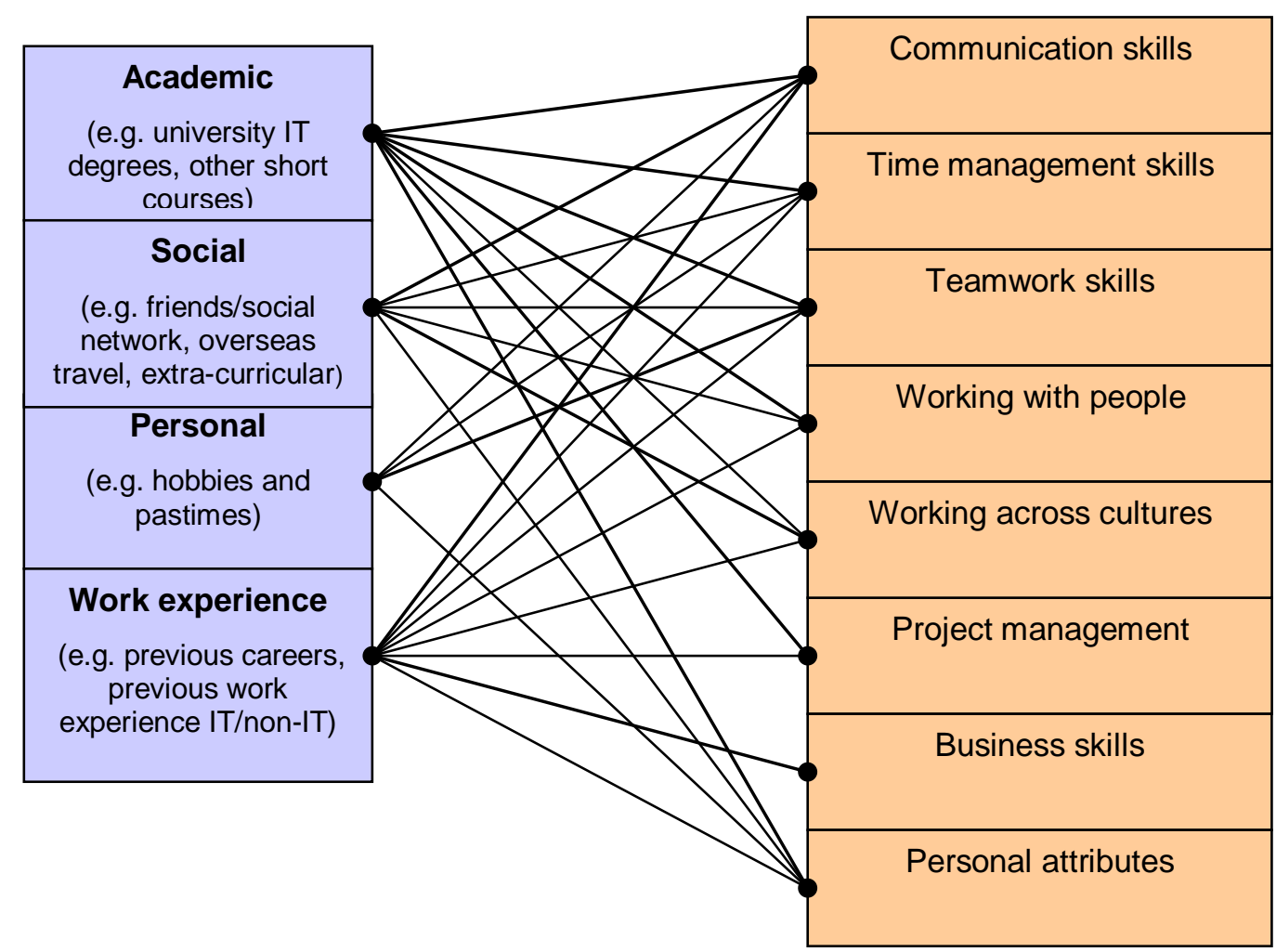

\section{Figure 1: Relationships between sources of professional skills and professional skills}

Before discussing these findings, a brief overview of the question of why graduate attributes should not be an add-on to existing courses and the need to have graduate attributes embedded in subjects is provided as a context to the findings.

\section{Generic graduate attributes should not be an add-on to existing courses}

While the importance of the soft skills in any workplace is emphasized by some studies, in IT it is essential not to separate these generic skills from the technical nature of IT work. In the real world, graduates report that they face situations where they need to integrate their professional skills and technical skills. Litchfield and Nettleton (2008), as a part of their work ready project at the University of Technology Sydney (UTS), recommend sharing across faculties tasks designed to assist the acquisition of generic work skills. This is appropriate as long as those tasks are then contextualised to a profession so students appreciate their relevance (Frawley \& Litchfield, 2009).

Many professional undergraduate degrees have a capstone course in the final year. This usually involves project work on a real world problem with a focus on the interaction of theory and practice. The aim of such projects is to give students exposure to the industry and can include real workplace assessors and possibly real or simulated interviews with clients and supervisors. The assessment of these projects should take into consideration not 
only assessment of the technical content based on the project deliverables, but also assessment of the development and use of professional skills such as communication skills, time management, teamwork, project management, business skills and self-reflection abilities. It is desirable that project problems are designed to be open, ambiguous and broad with students from different cultures and languages interacting with real workplace supervisors and university supervisors. Students should be asked to present their work at industry meetings to gather feedback.

Rossin and Hyland (2003) studied two project work groups from the information systems departments in two UK universities. In each case, students acted as consultants to clients and tutors assumed an advisory role to facilitate the project work. They found that the advantages of group work-based learning included: students training each other, both in technology and non-technical areas (the cascading effect of skills and knowledge was strong); conducting peer assessment; undertaking individual self-assessment (personal diaries) and the submission of group-based work deliverables for assessment. Such capstone projects have great potential to develop contextualised professional skills for IT graduates.

While the advantages of group work-based learning are clear, issues do arise if lecturers do not understand the transfer of generic skills between contexts and are not familiar with learning theory. Hence, students may be disadvantaged because of the approaches to teaching and learning used in classrooms (Crebert et al., 2004a; 2004b). Bridges (1993) describes 'transferring skills' as higher order skills that enable a person to select, adapt, adjust and apply his or her skills to different situations across different social contexts and across different cognitive domains. The development of such skills within a classroom setting requires specifically constructed tasks within the teaching and learning program.

The differing understandings and interpretations of generic graduate attributes present an obstacle to the consistent implementation of a graduate attributes framework across faculties. A further challenge for all universities is how to encourage student selfdevelopment and assessment for lifelong learning and reflective practice. This seems to be an area of deficiency in many graduates and development of this attribute through existing teaching, learning and assessment practices is often lacking.

\section{Major study finding: Cultural awareness and ability to work with cultures is a skill which is needed in IT but is often absent from graduate attributes}

\section{Ability to work with people from different cultures}

Graduates' work frequently requires them to communicate with a variety of people from different departmental groups with different cultures within their own organization, both locally and overseas. In addition, multinational and often global teams or clients are involved in IT projects. Consequently, cultural complexity arises due to the different cultures which may have different values and beliefs. Graduates have to take extreme care in composing all communication to deliver their message in a simple, clear, professional and timely manner. In this context, cultural awareness and communication are strongly related skills.

Graduates need to be aware of the nature of the group with whom they are talking. Communicating with technical teams is different from communicating with business teams. These two groups have varied professional culture and language requirements. Even within the same professional group, the use of technical language can be complicated, especially if the peers are from different overseas offices. Graduates need to be conscious of the recipient 'culture'. Gender differences can sometimes introduce yet another form of culture.

When a graduate is working on a project that uses different language systems or translations it is essential for graduates to acknowledge the complexities involved in developing a satisfactory product for the clients. One graduate described her experience with an 
international client as stressful, tedious and frustrating because of language and cultural differences that arose during the interactions between their Australian office, overseas offices and the client's overseas office.

We had an e-book campaign.......... This e-book had to get translated into let me see, simplified Chinese, traditional Chinese, Korean and then it was sent over to Europe to get translated into Russian, Spanish and a couple of others.... However, because we had a really lengthy backwards and forwards with the client .... it was an international campaign and I can understand that. ..... They were immensely particular about everything.... manager who was working with me must have recorded in excess of 100 emails with said client about this project, which is insane.

\section{Awareness of cultural barriers}

While working on international sites it is important for graduates to be aware of local customs, values and beliefs, for example having knowledge of local politics, holiday periods and food habits. One graduate was surprised when the customer made them wait until after a certain time because he did not like to be disturbed during certain times of the day.

Some people make you wait so they can finish their lunch before you can start work. That's happened to me.... When someone we sent out, an engineer on site, and the customer said, you've got to wait l've got to finish my lunch. So we had to just wait there.... So the timing and knowing the local customs there on top of the language issues as well....

Language barriers are usually overcome by the use of translators. When the translators are not reliable project management plans can be affected. A graduate described her dilemma in working with translators and how that affected her project management plans.

...all of a sudden we are working with a translation team. We have to work out exactly what they can do, how they are going to do it and how much it is going to cost as well. All that gets taken into account.......but for the most part when there is translation... it is really my problem.

Another graduate in a helpdesk role stated how he had to communicate with clients who had a strong accent, and as a result their English was hard to understand. Graduates in those situations have to be polite while facilitating communication either by use of a slower pace or translators.

Although the ability to work with people from different cultures and awareness of cultural and language barriers was strongly indicated as a requirement by many IT graduates in this study, it is not one of the threshold skills developed for the ALTC by Wright et al. (2010). This is surprising in light of the attention given to the development of cultural competence of staff and students in universities generally. While development of the skills required for working in such international projects can be fully developed only when graduates are on the job, an initial awareness and some development during university studies is not impossible and would be valued by students. The next section elaborates on this proposition.

\section{Maximising and using diversity in the university environment to assist IT graduates to develop social and cultural skills for the global workplace}

IT graduates need relevant cultural and communication skills to work in an industry that is global, multi-national and involves clients and colleagues from different countries and cultures. They also need to be aware of local customs and practices when they go on overseas business trips. In addition to the ability to work with people from different cultures, 
graduates need skills to work with people from different industry sectors, people from different age groups and with different experience levels in the hierarchy. Oliver, Jones, Tucker \& Ferns (2007b) state that graduates with international perspectives are able to consider how issues might impact on people in other parts of the world and graduates with intercultural perspectives are able to consider how issues might impact on people from other cultures.

According to Jenkins (1995) the link between the effectiveness of graduates in the workplace and a global perspective cannot be ignored. Universities could be responsible for developing graduates who fit into global workplaces. Similarly, Fuller and Scott (2009) discuss the need for global graduates and the development of job-readiness and employability skills in a global context. This is particularly relevant for the IT industry. Oliver et al. (2007b) reported that employers surveyed in their study commented that their graduates lacked international perspective and intercultural understanding.

Social and cultural skills are those skills that graduates need to work effectively with people from different cultures and different professions (technical and non-technical), such as building and maintaining professional relationships with peers and customers. Within Australian universities, particularly in IT departments, both staff and students come from a diverse range of ethnic and cultural backgrounds. This diversity could be used to help build these skills.

Universities could also tap into a different form of diversity and encourage collaboration between students in different disciplines and promote and facilitate socialisation between students from different courses, both on academic and cultural and social grounds (Barkley, Cross \& Major, 2005; Trigwell, 2005; Webb, Dawes \& Egodawatta, 2011; Schaffer, 2012). Faculties should consider the possibility of developing cross faculty projects for students although this can present practical challenges. While forming project groups, the ideal is to form diverse groups with a mix of students from different age groups, with or without previous work experience. The development of socio-cultural and professional skills could be encouraged by healthy intra and inter-university competitions such as debates. Encouraging student volunteers to plan and conduct major events on campus and increasing the interaction between students from different cultures will also help in the development of culturally sensitive global graduates.

Universities need to consider allocating dedicated resources to develop cultural awareness amongst their students through whatever is realistic and affordable, although there are several practical challenges to overcome. Many university students cannot afford the time for social activities because they are working in part-time jobs to fund their living and study expenses. These jobs are often low level and offer few opportunities for the development of social skills. Another obstacle for socialisation is that students from non-English speaking backgrounds are sometimes reluctant to participate in social activities at universities. The challenge is for universities to engage all their graduates in socialisation processes while they are studying.

The graduates in a study conducted by Crebert et al. (2004a) chose 'group work' (from a list of options) as the most effective context for the development of the university's stated generic skills and abilities. In addition, during work placements, graduates believed, that being given specific responsibility and working collaboratively with colleagues were critical for skill development. Graduates also stated that while teams at university were based on friendships, socio-cultural backgrounds and academic standards, at work they had to team up with people who might be different socially and professionally. In the study reported in this paper, IT graduates believed that the teamwork they engaged in at university assisted to some extent with the development of teamwork skills. However, the type of teamwork skills required in typical IT work settings, (for example, working with culturally diverse international teams in different time zones), were quite different. Nevertheless, they indicated that any 
group work-based learning had a greater impact on personal and social development than independent learning.

The value of teamwork (Engestrom, 1996), lifelong learning that views learning as 'inescapably a social creation' (Ranson, 1998) and the notion of collective intelligence (Brown \& Lauder, 1995) are highlighted by group work-based learning (both at university and workplaces). Guile and Hayton (1999) suggest that this is the case, even in the sphere of IT in which individual learning seems to predominate. Lave and Wenger (2002) describe the social context of learning in terms of 'legitimate peripheral participation' and the different ways in which newcomers move from being an outsider to an insider (in workplace learning). They view learning as a part of social practice. Rossin and Hyland (2003) propose group work-based learning to provide opportunities for training for employment and for personal and social development (moral, cognitive and social benefits to its members and to the wider community). The process rather than just the learning outcomes is emphasised by the social context of learning. They claim that social learning and communities of practice serve as mechanisms for personal, social and self-development of graduates.

Socialisation at university could be achieved through encouraging student participation in work placements, internships, involvement in student organisations, networking and career building contacts. Socialisation has the potential to provide graduates with opportunities to develop their social, communication and interpersonal skills. Universities should maximise and utilise their environments to develop the social and cultural skills of their graduates. For example, this study showed that communication requirements vary across workplaces, based on the scope and kinds of communication and norms of workplace requirements and culture. Communication in a hierarchical, oral, directive (command) culture is different from negotiations with self-managed teams in a workplace for a work based decision-making process (Billett, 2000, p.145). These workplace cultural differences should be highlighted to graduates before they enter the workforce so they do not experience 'culture shock'.

Communication skills, teamwork skills and the ability to work with people from different cultures are the most obvious skills that were developed from increased socialisation with university friends and professional peers as shown in the study findings. It has been reported in previous studies that graduates who actively participated in student organisations, internships and in organising or planning social and cultural events during university studies, perceived their courses as more relevant and useful than those who had not been so involved (Shruptrine \& Willenborg, 1998; Sleap \& Reed, 2006).

\section{Conclusion}

An increasingly important aspect of university preparation for the workforce is the attention to graduate attributes. Despite of the significance of cultural awareness and the ability to work with different cultures for professional graduates, there is little reference to the development of these skills in the current graduate attributes of many universities. These are of particular importance for IT degrees and courses. Even where such an attribute, often expressed as 'global citizen', is listed, there is no assurance that such skills are translated into learning and assessment resources. This paper has considered how universities might maximise the use of diversity on their campuses to assist with the development of cultural skills in graduates. In addition to this, faculties need frameworks beyond current graduate attributes to successfully address the development of skills such as the ability to work across different cultures. In conclusion, given the significance of graduate attributes at university, faculty and course level, it is of concern that they are often seen as yet another instrument for compliance rather than providing a focus for teaching and learning. There remains work to be done to ensure that students are not only aware of the importance of graduate attributes, but also that these can be achieved through student learning and assessment experiences. Furthermore, graduate attributes frameworks need to be reviewed for specific professional skills for individual professions. 


\section{References}

ACS (2013). ACS Accreditation - Document 2 Application Guidelines 15 October 2013. Australian Computer Society. Retrieved from http://www.acs.org.au/ data/assets/pdf file/0010/24499/ACS-AccreditationDocument-2-Application-Guidelines-15-Oct-2013-1.pdf

ALTC (2010a). ALTC Discipline Scholars begin. Australian Learning and Teaching Council. Retrieved from http://www.altc.edu.au/april2009-altc-discipline-scholars-begin

ALTC (2010b). Engineering and ICT Learning and Teaching Academic Standards Statement. Australian Learning and Teaching Council. Retrieved from http://www.olt.gov.au/resource-engineering-ict-Itas-statement-altc-2010

ALTC (2010c). Learning and Teaching Academic Standards Project. Sydney: Australian Learning and Teaching Council. Retrieved from http://www.olt.gov.au/system/files/altc standards.finalreport.pdf

Barkley, E., Cross, K. \& Major, C. (2005). Collaborative Learning Techniques. A handbook for college faculty. San Francisco: Jossey-Bass.

Barrie, S.C. (2004). A research-based approach to generic graduate attributes policy. Higher Education Research \& Development, 23(3), 261-275.

Barrie, S.C. \& Prosser, M. (2003). An aligned, evidence-based approach to quality assurance for teaching and learning. Proceedings of the Australian Universities Quality Forum 2003. Melbourne, 271-276.

Biggs, J. (2003). Teaching for quality learning at university (2nd edition). Buckingham: SRHE and Open University Press.

Billett, S. (2000). Performance at work: Identifying smart work practice. In R. Gerber \& C. Lankshear (Eds.), Training for a smart workforce. London and New York: Routledge, pp. $123-150$.

Boud, D. \& Solomon, N. (2006). Work based learning, graduate attributes and lifelong learning. In P. Hager \& S. Holland (Eds.), Graduate attributes, learning and employability. Springer, pp. 207-220.

Bowden, J., Hart, G., King, B., Trigwell, K. \& Watts, O. (2000). Generic Capabilities of ATN university graduates. Retrieved from http://www.clt.uts.edu.au/ATN.grad.cap.project.index.html

Bradley, D., Noonan, P., Nugent, H. \& Scales, B. (2008). Review of Australian Higher Education: Final Report. Australian Government. Retrieved from http://www.innovation.gov.au/HigherEducation/Documents/Review/PDF/Higher\%20E ducation\%20Review Title\%20page\%20to\%20chapter\%202.pdf

Bridges, D. (1993). Transferable skills: A philosophical perspective. Studies in Higher Education, 18(1), 43-51.

Bridgstock, R. (2009). The graduate attributes we've overlooked: Enhancing graduate employability through career management skills. Higher Education Research and Development, 28(1), 31-44.

Brown, P. \& Lauder, H. (1995). Post-Fordist possibilities: Education, training and national development. In L. Bash \& A. Green (Eds.), Youth, Education and Work. London: Kogan Page.

Business Council of Australia (BCA) \& Australian Chamber of Commerce and Industry (ACCI). (2002). Employability Skills for the Future. DEST. Retrieved from http://www.dest.gov.au/ty/publications/employability_skills/final_report.pdf

Crebert, G., Bates, M., Bell, B., Patrick, C. \& Cragnolini, V. (2004a). Developing generic skills at university, during work placement and in employment: Graduates' perceptions. Higher Education Research and Development, 23(2), 147-165. 
Crebert, G., Bates, M., Bell, M., Patrick, C.J. \& Cragnolini, V. (2004b). Ivory tower to concrete jungle revisited. Journal of Education and Work, 17(1), 47-70.

Deakin University (2013). Developing graduate attributes: Embedding graduate attributes in the curriculum. Deakin University. Retrieved from http://www.deakin.edu.au/itl/pd/tlmodules/curriculum/grad-attrib/grad-attr-06.php

Engestrom, Y. (1996). Innovative learning in work teams: Analysing cycles of knowledge creation in practice. Paper presented at the international conference Work and Learning in Transition: Toward a Research Agenda. San Diego: Sage Foundation..

Etzkowitz, H. \& Leydesdorff, L. (2000). The dynamics of innovation: From national systems and "Mode 2" to a triple helix of university-industry-government relations. Research Policy, 29,109-123.

Frawley, J. \& Litchfield, A. (2009). Engaging students and academics in work-ready learning contextualised for each profession in the curriculum. Proceedings of the 32nd HERDSA Annual Conference, 6-9 July, Darwin, Australia. Retrieved from http://www.herdsa.org.au/wpcontent/uploads/conference/2009/papers/HERDSA2009 Frawley J.pdf

Fuller, T. \& Scott, G. (2009). Employable global graduates: The 'edge' that makes the difference', Proceedings of the 18th Annual Teaching Learning Forum, 29-30 January 2009, Perth: Curtin University of Technology. Retrieved from https://otl.curtin.edu.au/events/conferences/tlf/tlf2009/refereed/fuller.html

Guile, D. \& Hayton, A. (1999). Information and learning technology: The implications for teaching and learning in further education. In A. Green \& N. Lucas (Eds.), FE and lifelong learning: Realigning the sector for the twenty-first century. London: Institute of Education.

Hager, P. \& Holland, S. (Eds.) (2006). Graduate attributes, learning and employability. The Netherlands: Springer.

Harvey, L. (2001). Defining and measuring employability. Quality in Higher Education, 7(2), 97-109.

James, B., Lefoe, G. \& Hadi, M. (2004). Working 'through' graduate attributes: A bottom-up approach. Proceedings of the HERDSA 2004 International Conference. Milperra, NSW HERDSA.

Jenkins, A. (1995). Linking skills, academics and disciplinary concerns. In A. Jenkins \& A. Ward (Eds.), Developing skill-based curricula through the disciplines: Case studies of good practice in geography, SEDA Paper 89, pp. 121-131.

Kamvounias, P. \& Thompson, D. (2008). Assessing graduate attributes in the business law curriculum. Journal of the Australasian Law Teachers Association, 1(1), 181-195.

Lave, J. \& Wenger, E. (2002). Legitimate peripheral participation in communities of practice. In F. Reeve, M. Cartwright \& R. Edwards, R. (Eds.), Supporting lifelong learning: Volume 2: Organizing learning. London: Routledge Falmer/Open University.

Litchfield, A. \& Nettleton, S. (2008). Work-ready wiki: Supporting the learning and teaching of professional graduate attributes. Proceedings of 25th annual ASCILITE conference, Melbourne. Retrieved from http://www.ascilite.org.au/conferences/melbourne08/procs/litchfield.pdf

Lowden, K., Hall, S., Elliot, D. \& Lewin, J. (2011). Employers' perceptions of the employability skills of new graduates. London: University of Glasgow SCRE Centre and Edge Foundation.

Nankervis, A., Compton, R. \& Baird, M. (2005). Human resource management (5th ed.), Southbank, Melbourne: Thomson.

Oliver, B., Jones, S., Ferns, S. \& Tucker, B. (2007a). Mapping curricula: Ensuring workready graduates by mapping course learning outcomes and higher order thinking skills, Evaluations and Assessment Conference, Brisbane, Australia. Retrieved from 
http://www.eac2007.qut.edu.au/proceedings/proceedings ebook.pdf

Oliver, B., Jones, S., Tucker, B. \& Ferns, S. (2007b). Are our students work-ready?

Graduate and employer feedback for comprehensive course review. Evaluations and Assessment Conference. Brisbane, Australia. Retrieved from http://www.eac2007.qut.edu.au/proceedings/proceedings ebook.pdf

Ranson, S. (Ed.) (1998). Inside the learning society. London: Cassell Publishers.

Rossin, D. \& Hyland, T. (2003). Group work-based learning within higher education: An integral ingredient for the personal and social development of students. Mentoring \& Tutoring: Partnership in Learning, 11(2), 153-162.

Schaffer, S., Chen, X., Zhu, X. \& Oates, W. (2012). Self-efficacy for cross disciplinary learning in project-based teams. Journal of Engineering Education, Vol. 101, No.1, 82-94.

Scott, G. \& Yates, K.W. (2002). Using successful graduates to improve the quality of the undergraduate engineering programs. European Journal of Engineering Education, 27(4), 363-378.

Seitel, S. (2011). A skills shortage or unrealistic expectations? Retrieved from http://www.huffingtonpost.com/susan-seitel/us-skills-shortage-_b_1124279.html

Shruptrine, F.K. \& Willenborg, J. F (1998). Job experiences of marketing graduates Implications for marketing education. Marketing Education Review Spring, 8(1),1-11.

Sleap, M. \& Reed, H. (2006). Views of sport science graduates regarding work skills developed at university. Teaching in Higher Education, 11(1), 47-61.

Thompson, D., Treleaven, L., Kamvounias, P., Beem, B. \& Hill, E. (2008). Integrating graduate attributes with assessment criteria in business education: Using an online assessment system. Journal of University Teaching and Learning Practice, 5(1), 3448.

Trigwell, K. (2005). Teaching-research relations, cross disciplinary collegiality and student learning. Higher education, 49 (3), 235-254.

Webb, R., Dawes, L.A. \& Egodawatta, P. (2011). Creating better learning environments by cross disciplinary collaboration; a civil engineering and surveying linkage. In Proceedings of the 2011 Conference Australasian Association of Engineering Education. AAEE, Perth.

Wenger, E., McDermott, R. \& Snyder, W. (2002). Cultivating communities of practice: A guide to managing knowledge. Boston, Massachusetts: Harvard Business School Press.

Wright, S., Hadgraft, R. \& Cameron, I. (2010). Engineering and ICT learning and teaching: Academic standards statement. Retrieved from http://www.olt.gov.au/resources/3899,4060?text=accreditation\&solrsort=score\%20de $\underline{\mathrm{SC}}$

Yorke, M. (2006). Employability in higher education: What it is - what it is not. Heslington, York: The Higher Education Academy. Retrieved from http://www.heacademy.ac.uk/assets/York/documents/ourwork/tla/employability/id116 employability in higher education 336.pdf 